University of Puget Sound

Sound Ideas

All Faculty Scholarship

Faculty Scholarship

Spring 2018

\title{
Classification as Narrative: A Renewed Perspective on a Longstanding Topic in Ethnobiology
}

Denise M. Glover

University of Puget Sound, dglover@pugetsound.edu

Follow this and additional works at: https://soundideas.pugetsound.edu/faculty_pubs

Part of the Alternative and Complementary Medicine Commons, Anthropology Commons, Biodiversity Commons, Other Linguistics Commons, and the Systems Biology Commons

\section{Citation}

Glover, Denise M. 2018. "Classification as Narrative: A Renewed Perspective on a Longstanding Topic in Ethnobiology." Journal of Ethnobiology 38(1):105-123.

This Article is brought to you for free and open access by the Faculty Scholarship at Sound Ideas. It has been accepted for inclusion in All Faculty Scholarship by an authorized administrator of Sound Ideas. For more information, please contact soundideas@pugetsound.edu. 


\title{
Classification as Narrative: A Renewed Perspective on a Longstanding Topic in Ethnobiology
}

\author{
Author(s): Denise M. Glover \\ Source: Journal of Ethnobiology, 38(1):105-123. \\ Published By: Society of Ethnobiology \\ https://doi.org/10.2993/0278-0771-38.1.105 \\ URL: http://www.bioone.org/doi/full/10.2993/0278-0771-38.1.105
}

BioOne (www.bioone.org) is a nonprofit, online aggregation of core research in the biological, ecological, and environmental sciences. BioOne provides a sustainable online platform for over 170 journals and books published by nonprofit societies, associations, museums, institutions, and presses.

Your use of this PDF, the BioOne Web site, and all posted and associated content indicates your acceptance of BioOne's Terms of Use, available at www.bioone.org/page/ terms of use.

Usage of BioOne content is strictly limited to personal, educational, and non-commercial use. Commercial inquiries or rights and permissions requests should be directed to the individual publisher as copyright holder. 


\title{
Classification as Narrative: A Renewed Perspective on a Longstanding Topic in Ethnobiology
}

\author{
Denise M. Glover ${ }^{1}$
}

\begin{abstract}
The present work offers a renewed perspective on natural-kind classification in the field of ethnobiology, one that focuses on analyzing higher-order classifications as a form of narrative. By examining changes in classification of materia medica in three main medical/pharmacological texts from three time periods of the Tibetan medicine tradition, we see an overarching shift in classification from a focus on medical efficacy to one on material substance and morphology, thus suggesting influence from pre-twenty-first century western, Linnaean science. The work then links this historical narrative to the complexities of classification of materia medica among contemporary doctors of Tibetan medicine in the People's Republic of China, who utilize several classificatory schemata. The work encourages continued research in the area of diachronic classification, particularly in terms of what can be gleaned about cultural, political, and social changes in a tradition.
\end{abstract}

Keywords: classification; Tibetan medicine; narrative; materia medica; history and context in classification

\section{Introduction}

Why do ethnobiologists study systems of natural-kind classification? From the perspectives of anthropology and cognitive science, such systems are revealing in terms of what they can tell us about human cognition and culture, including species-wide similarities, as well as cultural differences. Some of the earliest contributions in ethnobiological theory revolved around making sense of the systems of classification that exist in multiple communities throughout the world in terms of what these systems indicate about human interaction with and conceptualizations of natural kinds (Berlin 1973; Berlin et al. 1973; Brown 1984, 1985; Bulmer 1967; Hunn 1975, 1976, 1982). With Berlin's 1992 magnus opus, Ethnobiological Classification: Principles of Categorization of Plants and Animals in Traditional Societies, many of the core principles that had been under investigation by ethnobiologists for nearly 30 years were well established. What remained were for ethnobiologists to continue to test the principles that Berlin and others set forth and to continue to discuss the significance of studying natural-kind classification systems.

An important vein of inquiry in ethnobiological studies of classification has included attention to change within classificatory systems, history, and context. Brent Berlin (1992) and Cecil Brown (1984), in particular, consider developmental stages of inclusive hierarchy, most convincingly related to modes of economy and social structure, where particular categories and naming patterns are identified cross-culturally through an evolutionary paradigm. Roy Ellen and David Reason (1979) point to the significance of social context in understanding systems of natural-kind classification, arguing that classification systems are not abstracted from real-world situations but embedded in socio-cultural processes. Other historical works, such as the ornithological study by Tim Birkhead (2008), trace the connections between categories of natural kinds, as identified by 
various scholars through several centuries and in various cultural contexts, mainly in Europe. Relatedly, other approaches in ethnobiology use the method of historical linguistics, where cultural change (and contact) can be revealed through examination of lexicon (Brown et al. 2013).

With this piece, I propose an approach to classification that is based on a historical orientation to classification systems, but one that is also strongly grounded in contemporary ethnography and the contemporary usage of a classificatory system among a particular group of people. This approach has been largely shaped by the work of Ellen and Reason (1979) and their emphasis on social context and is an expansion and new interpretation of previous work of mine on similar topic (Glover 2005, 2010). Rather than thinking of classification systems as relatively asynchronic and static (or, one might prefer, the term stable) representations of the natural world, the orientation I propose asks that we consider classificatory systems diachronically, as reflections of history and subject to change. This orientation reveals classification as a form of narrative, potentially illuminating important cultural, social, political, and economic changes occurring in connection with a system over time. Furthermore, the narrative explored herein encompasses the present-day classificatory realities of the medical practice of Tibetan doctors in the People's Republic of China (PRC), extending the historical narrative to include the present moment.

Of primary consideration in the orientation that I am proposing is some degree of time-depth. Much of the research on contemporary classification that ethnobiologists have engaged in does not lend itself well to diachronic analysis, since it has been largely based on current systems of classification, mainly in oral or non-literate traditions (what Berlin [1992] terms "traditional societies"). The orientation I am proposing comes out of my own research examining the classification system in
Tibetan medicine, which includes careful study of medical texts, as well as the study of classification among contemporary doctors of Tibetan medicine. What I have discovered is that because of the long, literate tradition of Tibetan medicine-and the centrality of literacy in the training of doctors of Tibetan medicine-the classification schemata that even contemporary doctors (as classifiers) engage with are variable, revealing shifts in classificatory considerations over time. What appeared to me at first glance like a jumble of conflicting information (how plants could be classified in multiple ways by the same people) shows instead a layering of meaning through time, with significant adumbrations of history.

This focus on a layering of meaning and/or change in meaning throughout time, and, thus, a turn to classification as narrative, does not subtract from understanding the cognitive significance of classificatory systems. In fact, it is complementary. As Berlin (1992) has successfully argued, higher order categories-those that occur above his folk generic (close to scientific species) rank-are those that have the most cultural variability. It is exactly at this level where history can be revealed. In a related vein, Berlin (1992) has argued for a distinction between what he terms "general-purpose" and "special-purpose" classifications. The former are those supra-generic classifications derived from a broad spectrum of flora or fauna with no specific function, while the latter are classifications for particular purposes, such as "[those for] economic or cultural significance, for example, trees useful as fuel, medicinal plants, and so forth" (Berlin 1992:152). The present study is focused on "special-purpose," supra-generic classification in the Tibetan medical tradition. Again, a Berlinian (1992) argument would posit that this examination is in the realm of culture. Revelations of cultural history do not exclude or preclude considerations of human cognition but rather augment our understanding of variations in classification. In the texts we 
will examine here, I will demonstrate how there have been important shifts in the way medicinal ingredients have been classified (and thus conceptualized) in the past and how they are also conceptualized today. These shifts reveal a narrative that indicates the influence of Linnaean science on Tibetan medicine, which enriches our understanding of the Tibetan ethnomedical and ethnobiological world, and our understanding of Tibetan history, as well as the cognitive implications of these shifts.

\section{Methods}

I examine the classificatory schemata of three significant medical texts utilized by contemporary doctors of Tibetan medicine in the PRC. The majority of my research among Tibetan doctors since 1999 has been in China's southwest, in the northwestern reaches of Yunnan Province. From an ecological perspective, this area is a hotspot of biological (and cultural) diversity, recognized as such since 2003 by the designation of the Three Parallel Rivers of Yunnan Protected Area, a UNESCO World Heritage Site. Due to its biological diversity, much of the materia medica used in the production of Tibetan and Chinese medicines in the PRC is sourced from here and local doctors, whether traditionally trained in institutional (hospital, college) settings or through family lineage, are important holders of traditional ecological knowledge. Most of the doctors with whom I have worked live and practice (and some produce) medicine in the town of Rgyalthang, which was officially renamed Shangrila in 2002. The town is located in a Tibetan autonomous prefecture; such a designation means that many decisions over local policy are in the hands of the prefectural government, consisting of a majority of ethnic Tibetans. Autonomous areas in the PRC were established after the Communist Revolution of 1949 based on an ideal of autonomous (with degree) self-rule by non-Han Chinese (ethnic) peoples. A few of the most consequential results of this governance in the Rgyalthang area include the establishment and funding of a hospital of traditional Tibetan medicine, where I have spent the majority of my research hours over the past nearly two decades, and an economy increasingly dependent on tourism (the area has become a mecca for those seeking Shangrila, a "paradise on earth"), where Tibetan culture, including medicine and medicinal ingredients, are significant commodities in a global economy of cultural and material exchange.

My perspective on Tibetan medical classifications is based on understanding I have gained by reading texts, but also by discussing these topics with doctors of Tibetan medicine, mainly in Rgyalthang (I have also talked with doctors in the US and India, but less extensively). In fact, the doctors with whom I have worked were the ones that pointed me toward written texts to further our conversations about classification, since they engage deeply with these texts in matters of classification, diagnosis, treatment therapies, etc., and it is from their authoritative lead that I herein focus on these sources. Therefore, although I am discussing written texts, two of which were published before the twentieth century, the classificatory schemata in these texts are relevant to contemporary doctors, who utilize these schemata on a regular basis. For doctors of this literate tradition, texts are not merely recordings of previous knowledge; they are in fact direct points of access to the knowledge as revealed by elders (and recorded for posterity). Texts are central nodes in knowledge transmission. Since texts are memorized by doctors as students before they even understand much of what the texts mean, the classificatory schemata are cognitively embedded early on in a doctor's training. Don Bates (1995:12) would define this as a gnostic system of knowing, where texts are seen as "revelations of transcendent authorities" although, due to the style in which most of the texts are written in gnostic traditions, 
open to interpretation by an experienced tradition-holder. This issue of interpretation is closely linked to that of translation and, for some categories explored herein, there are more than one possible translation, which adds to the complexity and challenge of semantic analysis. For sake of clarity, I will generally choose one gloss for a term upon first encounter and in table summaries (often with a note as to possible other translations), but, within the text, will draw out some of the nuanced differences in the meanings of these categories via various translations.

The texts under examination here are central to the training and practice of contemporary doctors of Tibetan medicine. The first is the classic called the Four Tantras (Rgyud bzhi 1978), a text with core elements that date to the eighth century, but which was likely written mainly during the twelfth century by a Tibetan physician named Yuthok Yonten Gonpo, the Younger. This text includes discussions of materia medica, pharmacology, diagnosis, disease etiology, treatments, and medical ethics. It is memorized by doctors in the course of their training, through rote memorization and other strategies of embodied memorization (Glover 2011; Millard 2002). To pass the necessary exams to become a doctor of Tibetan medicine, one must recite, from memory, long stanzas from the Four Tantras ${ }^{1}$. Doctors say that this is necessary because, while practicing as a physician or a pharmacist, one cannot stop to look up information; having this text and the knowledge that it contains memorized by heart is a much faster and reliable method.

The second text under consideration, the Crystal Garland of Medicine (Shel Gong 'Phreng; Bstan 'dzin Phun tshogs 1980), is from the eighteenth century and is strictly focused on materia medica; no discussion of diagnosis, treatment, disease etiology, or other medical topics are included in the text. Some doctors with whom I worked knew this text well, although it was not clear that they had memorized it, and they, in fact, are not tested for memorization of this text in their training, yet there does appear to be some influence on their conceptualizations of materia medica, as I will explain.

The third text examined here, the Crystal Mirror (Shel gyi Me long; Dga' ba'i Rdo rje 1995), was first published in 1995 in Beijing and was written by the contemporary and well-known Tibetan physician Gawai Dorje. While this text does not appear to be one that is memorized by students (at least not during the time of my fieldwork), it does function as an important reference text for doctors, especially when in the field collecting and identifying plants. One of the significant features of this volume is an appendix with nearly 900 color photos of materials discussed in the text. This book also appears to be important in India, as I have heard reports that doctors there use it as well.

Classifications cannot be effectively understood in isolation outside of socio-cultural-eco-political events (Ellen 1993; Ellen and Reason 1979; Glover 2005). Thus, in this multi-ethnic (but nominally Tibetan) place, the act of naming and categorizing within a subject even as "innocuous" as materia medica can be read as a political, social, and/or cultural act. To that end, I work almost exclusively with nomenclature of categories and taxa in Tibetan, although the majority of my speech with these doctors has taken place in Mandarin Chinese, since I am fluent in Mandarin. While the doctors themselves use Tibetan in their training and in the majority of their work, exceptions to this rule occur when necessary to communicate to the larger medical administration of the province or state, with practitioners of Tibetan medicine from other areas of the PRC or beyond, local workers, or foreign researchers, such as myself, when a common dialect of spoken Tibetan is not shared. Nonetheless, Tibetan is the preferred (and sometimes the only known) nomenclature among Rgyalthang doctors (and indeed many doctors 
in the Tibetan tradition) for the majority of materia medica and for many of the specific categories examined here. I have elsewhere discussed (Glover 2005:112-147) a form of code switching at work in the communications between myself and Rgyalthang doctors, where selective use of Tibetan in Mandarin-dominant conversations may function as a marker of ethnic identity and a symbol of ethnic pride.

\section{Analysis of Categories (Full Materia Medica and Plants Only) in Texts}

\section{Categorization of Materia Medica in Three Texts}

I begin by examining the classification of materia medica at large in the three texts (Table 1). Since Tibetan medicine includes use of plants, animals, salts, rock, earth, etc., I start with an analysis of the classifica- tion of all of these medicinal materials. Such an examination gives us an understanding of the overall system of natural-kind classification in the Tibetan medical tradition. Afterward, I examine the classification of plants only in two of the three texts (the oldest and the newest). The examination of plants alone will help us highlight specific points that will be made in the analysis of materia medica in general, most of which point toward a focus on physical and morphological features as the classificatory organizing principles.

\section{The Four Tantras}

Book Two of the Four Tantras is called the Explanatory Tantra (Bshad pa'i Rgyud); it contains a total of 31 chapters. Three of these chapters concern formulation of medicines, the various properties of medicines, and classification of materia medica.

Table 1. Comparison of categories of materia medica in the Four Tantras, the Crystal Garland, and the Crystal Mirror. Categories are left in the original order given in the texts, and given in English glosses. For Tibetan names, see Tables 2-4.

\begin{tabular}{|c|c|c|}
\hline Four Tantras ( $12^{\text {th }}$ century) & Crystal Garland (18 ${ }^{\text {th }}$ century) & $\begin{array}{l}\text { Crystal Mirror }\left(20^{\text {th }} \text { century }\right) \\
\text { *Treasures }\end{array}$ \\
\hline Precious Medicine & Precious Medicine & Precious Medicine \\
\hline Earth Medicine & Stone Medicine & Earth \& Stone Medicine \\
\hline \multirow[t]{2}{*}{ Stone Medicine } & Earth Medicine & Salt Medicine \\
\hline & & *Plants \\
\hline Woody Plant Medicine & Exudent Medicine & $\begin{array}{l}\text { Exudent [Mostly Plant] } \\
\text { Medicine }\end{array}$ \\
\hline Exudent Medicine & Woody Plant Medicine & Woody Plant Medicine \\
\hline Medicine from the Plains & Herbaceous Medicine from the Plains & Herbaceous Plant Medicine \\
\hline \multirow[t]{2}{*}{ Herbaceous Medicine } & Herbaceous Medicine & Grain medicine \\
\hline & *Salt Medicine & \\
\hline \multirow[t]{6}{*}{ Animal Medicine } & Animal Medicine & Animals \\
\hline & & *Mammal Medicine \\
\hline & *Crop/grain Medicine & *Bird Medicine \\
\hline & *Water Medicine & $\begin{array}{l}\text { *Non-aquatic \& aquatic } \\
\text { worms \& insects [and } \\
\text { reptiles] }\end{array}$ \\
\hline & *Fire Medicine & \\
\hline & *Mixed Medicine & \\
\hline
\end{tabular}

\footnotetext{
*Indicates that this is a new category, not found in an earlier text(s) discussed here.
} 
These are Chapter 19, Medicines: Taste and Post-digestive Taste (Ro dang zhu rjes); Chapter 20, Medicines: Efficacy (includes potency, strength, and attributes) (Nus pa: nus, stobs, yon tan); and Chapter 21, Medicines: Compounding (Sbyar thabs).

In Chapter 20, materia medica are divided into eight categories (Table 2). This scheme is generally the one referred to by Tibetan doctors when discussing materia medica classification and the text uses the Tibetan term for categories (bye brag) to organize materia medica. Chapters 19 and 21 also contain other schemata for grouping or classing materia medica (these other groupings will become important when I discuss variations in classifying). Chapter 20 does not give descriptions or definitions of each of these eight categories, although it does give examples. However, examples for categories four, five, and six (Woody Plant Medicine, Exudant Medicine, and Medicine from the Plains) are all listed together, with no punctuation or other linguistic markers to separate them; that is, the Four Tantras does not divide up the examples for each of these categories nor does it indicate which example is

Table 2. Categories of materia medica in the Four Tantras.

\begin{tabular}{|c|c|c|c|}
\hline English gloss & Tibetan name & Subtypes (English \& Tibetan) & Comments \\
\hline Precious Medicine & Rin po che yi sman & & $\begin{array}{l}\text { Includes metals and } \\
\text { stones }\end{array}$ \\
\hline Earth Medicine & Sa sman & & \\
\hline Stone Medicine & Rdo'i sman & & $\begin{array}{l}\text { Includes metals and } \\
\text { minerals }\end{array}$ \\
\hline $\begin{array}{l}\text { Woody Plant Medicine, or } \\
\text { Tree Medicine }\end{array}$ & Shing sman & $\begin{array}{l}\text { roots (rtsa ba) } \\
\text { trunk (Idum bu) } \\
\text { stems (sdong po) } \\
\text { branches (yal ga) } \\
\text { pith (rkang) } \\
\text { bark (zhun pa) } \\
\text { exudates/gum (thang chu) } \\
\text { leaves (lo ma) } \\
\text { flowers (me tog) } \\
\text { fruit ('bras bu) }\end{array}$ & $\begin{array}{l}\text { Subtypes are named } \\
\text { depending on which part } \\
\text { of the plant is utilized } \\
\text { Dash (1995) glosses this } \\
\text { category as "herbs" }\end{array}$ \\
\hline Exudant Medicine & Rtsi sman & $\begin{array}{l}\text { derived from roots, trees, and } \\
\text { animals (rtsi sman rtsa shing } \\
\text { srog chags las byung ba) }\end{array}$ & $\begin{array}{l}\text { Materials that exude } \\
\text { sticky substances or strong } \\
\text { scents }\end{array}$ \\
\hline Medicine from the Plains & Thang sman & $\begin{array}{l}\text { roots (rtsa ba) } \\
\text { tender branches (ngar pa) } \\
\text { leaves (lo ma) } \\
\text { flowers (me tog) } \\
\text { fruit ('bras bu) }\end{array}$ & $\begin{array}{l}\text { Subtypes are named } \\
\text { depending on which part } \\
\text { of the plant is utilized }\end{array}$ \\
\hline Herbal Medicine & Sngo sman & & $\begin{array}{l}\text { Dash (1995) glosses this } \\
\text { category as "salads" }\end{array}$ \\
\hline Animal Medicine & Srog chags sman & & \\
\hline
\end{tabular}


a representative of which category. Why they are listed together is not clear. Thus, it is difficult to know which substances fall under which category. I have had to rely on another text, the Blue Beryl (Baidur Sngon po; Sde srid Sangs rgyas Rgya mtsho 1973), a seventeenth century text written by the Fifth Dalai Lama's regent, Sangye Gyatso, for interpretation of examples of these categories. While this is not ideal (specification in the original text would have been more desirable), the Blue Beryl is generally recognized to be an edited edition of the Four Tantras and not a new text in its own right.

The eight categories given in the Four Tantras are provided in the chapter based on the nature/essence (ngo bo) of the ingredients (Table 2). Nature/essence describes the make-up of a substance (plant, animal, type of soil, etc.) depending on the composition of the five elements (earth, water, fire, air, and space) in that substance and, by extension, the therapeutic effect of the substance. While "element" is the common English translation of the Tibetan term 'byung, these are better thought of as subtle energies or states of existence rather than material ingredients; 'byung in Tibetan means emerging or coming forth (arising) and does not connote materiality. Thus, these categories are based on the intrinsic nature of energy that the substance has as a potentiality. Note that these classifications are provided in the chapter on efficacy. Efficacy refers to three aspects of a medicinal substance: potency (nus), strength (stobs), and attributes (yon tan). The Four Tantras states that the efficacy of a medicine is in part dependent on its nature/essence as well as on its taste (ro). In other words, the effect a substance has is dependent on the assemblage of five elements in that substance (its nature/essence), as well as its taste.

There are various translations possible for these categories which are not fully captured in a simple reduction to one term for each category. I have chosen to use the meanings as explained to me by doctors with whom I studied. The variety of translations provided by others (e.g., Dash 1994, 1995, 1997, 1998, 1999; Rechung 2001) suggest that some of the categories may be based on how the substance is to be processed and/ or what the final form is that the medicinal substance will take. For example, Vaidya Baghwan Dash's (1995) glosses of "decoctions" for thang sman, "herbs" for shing sman (otherwise usually "woody/tree medicine"), and "salads" for sngon sman draw our attention to medicine processing. In addition, if we consider the translation of thang sman as being "medicine from the plains" (which I do here) then where substances grow or occur is an important distinguishing characteristic of this group (habitat affects a plant's nature/essence and its composition of five elements). Additionally, this is an indication of the polysemous nature of many of these categories, with possible variations in meaning shifting through time. I will return to the importance of these challenges with translation below.

\section{The Crystal Garland of Medicine (Shel Gong 'Phreng)}

Authored by Geshe Tenzin Phuntsok (Bstan 'dzin phun tsogs; b. 1672), this text was written either in 1727 or 1737 (accounts vary). Tenzin Phutsok was a prolific writer, having authored over 30 works, the majority of which are medical texts. Finckh (1978:25) notes that his works are highly esteemed, in part because they were printed at the Derge (Sde dge) Monastery where the block-prints "are considered to be particularly reliable." The Crystal Garland of Medicine text deals exclusively with materia medica and identifies 13 categories of materia medica (Table 3). This text includes "new" categories of Salt Medicine, Medicine from Crops/grains, Water Medicine, Fire Medicine, and Mixed Medicine. It also lists three commonly used "vehicles" for medicine (sman rta [vehicles] gsum [three]): molasses (bu ram), sugar (ka ra), and honey (sbrang rtsi).

A significant aspect of this text is its arrangement into two parts, the first of 
Table 3. Categories of materia medica in the Crystal Garland.

\begin{tabular}{|c|c|c|c|}
\hline English gloss & Tibetan name & Subtypes (English \& Tibetan) & Comments \\
\hline $\begin{array}{l}\text { Precious } \\
\text { Medicine }\end{array}$ & $\begin{array}{l}\text { Rin po che } \\
\text { sman }\end{array}$ & & Metals \\
\hline Stone Medicine & Rdo'i sman & & \\
\hline Earth Medicine & Sa'i sman & & \\
\hline $\begin{array}{l}\text { Exudent } \\
\text { Medicine }\end{array}$ & Rtsi sman & $\begin{array}{l}\text { tree medicine (shing gi rtsi sman) } \\
\text { herbal medicine (Idum bu'i rtsi sman) } \\
\text { herbal medicine (sngo'i rtsi sman) } \\
\text { animal medicine (srog chags gyi rtsi sman) } \\
\text { stone medicine (rdo'i rtsi sman) }\end{array}$ & $\begin{array}{l}\text { The two types of herbal } \\
\text { medicines listed here can } \\
\text { be distinguished by those } \\
\text { that grow in a plains } \\
\text { environment (Idum bu'i } \\
\text { rtsi) and those that grow } \\
\text { at high altitude (sngo'i } \\
\text { rtsi sman); Wang (1994) } \\
\text { argues that the former are } \\
\text { "wet-growing" while the } \\
\text { latter are "dry-growing." }\end{array}$ \\
\hline $\begin{array}{l}\text { Woody Plant } \\
\text { Medicine, or } \\
\text { Tree Medicine }\end{array}$ & Shing sman & $\begin{array}{l}\text { fruit ('bras bu) } \\
\text { flowers (me tog) } \\
\text { leaves (lo ma) } \\
\text { stem (sdong bo) } \\
\text { branches (yal phran) } \\
\text { bark (pags pa) } \\
\text { gum/sticky matter/ exudent (tshi ba ste (thang } \\
\text { chu) }\end{array}$ & $\begin{array}{l}\text { Subtypes are discussed } \\
\text { depending on which part } \\
\text { of the plant is utilized/has } \\
\text { efficacy (nus pa). }\end{array}$ \\
\hline $\begin{array}{l}\text { Herbal Medicine } \\
\text { from the Plains }\end{array}$ & $\begin{array}{l}\text { Ldum bu 'am } \\
\text { thang sman }\end{array}$ & & $\begin{array}{l}\text { These are mainly } \\
\text { herbaceous plants } \\
\text { growing in open plains } \\
\text { areas. }\end{array}$ \\
\hline Herbal Medicine & Sngo sman & $\begin{array}{l}\text { roots (rtsa ba) } \\
\text { leaves (lo ma) } \\
\text { flowers (me tog) } \\
\text { fruit ('bras bu) }\end{array}$ & $\begin{array}{l}\text { Subtypes discussed } \\
\text { depending on which part } \\
\text { of the plant is utilized/has } \\
\text { efficacy (nus pa). }\end{array}$ \\
\hline & & $\begin{array}{l}\text { leaves, stems, flowers, fruit gathered together } \\
\text { as one (lo sdong me 'bras Ihan cig btu ba) } \\
\text { root, leaves, flowers, fruit gathered together } \\
\text { (rtsa lo me 'bras bcas yongs rdzogs btu ba) }\end{array}$ & $\begin{array}{l}\text { These are mainly high- } \\
\text { altitude herbaceous } \\
\text { plants, in contrast with } \\
\text { those from the plains (see } \\
\text { previous). }\end{array}$ \\
\hline Salt Medicine & $\begin{array}{l}\text { Lan tshwa'i } \\
\text { sman }\end{array}$ & & \\
\hline $\begin{array}{l}\text { Medicine } \\
\text { Derived from } \\
\text { Animals }\end{array}$ & $\begin{array}{l}\text { Srog chags } \\
\text { las byung ba'i } \\
\text { sman }\end{array}$ & & \\
\hline $\begin{array}{l}\text { Medicine from } \\
\text { Crops/grains }\end{array}$ & $\begin{array}{l}\text { Zhing gi lo } \\
\text { thog las byung } \\
\text { ba'i sman }\end{array}$ & & \\
\hline Water Medicine & Chu'i sman & & \\
\hline Fire Medicine & Me'i sman & & \\
\hline Mixed Medicine & $\begin{array}{l}\text { Gdus [sic] pa'i } \\
\text { sman }\end{array}$ & & \\
\hline
\end{tabular}


which discusses efficacy (nus pa) and the second of which lists the 13 categories of materia medica. This differs from the Four Tantras (and the Blue Beryl), where categories of materia medica are listed within the context of efficacy. Such a conceptual separation of categorization (based on nature/essence) from efficacy was a ground-breaking move by author Tenzin Phutsok; no longer is nature/essence (ngo bo) as related to efficacy the primary classificatory principle. This shift in how the principle of categorization was no longer directly linked to considerations of effect or medical efficacy allowed the acceptance of later works to consider physical characteristics of materia medica alone as classifying principles, which becomes essentially the principle of morphological classification (based on form, shape, etc., per the Linnaean tradition).

Where the separation of nature/ essence and efficacy originates is difficult to know, but is central to our understanding of this shift in classification. It is unlikely the influence of Carolus Linnaeus directly, since his Systema Naturae was published in 1735-at practically the same historic moment that the Crystal Garland of Medicine was published. Thus, is this the product of an individual innovation on the part of the author? Or, can this be tied to broader historical, political, social, and cultural events in the Tibetan socio-cultural-political world? Perhaps Linnaeus and Tenzin Phuntsok were influenced by an earlier work or a more general focus on morphology that was somewhat "global" (at least pan-Eurasian) in scope. Work by Katharina Sabernig, Ronit Yoeli-Tlalim, and others have shown the connections between Tibetan and western (Greek and Persian) medicines in the areas of anatomy, use of musk, urine analysis, and the development of some aspects of medical theory, such as the concept of "humors" (Akasoy et al. 2016; Garrett 2007; Sabernig 2016; Yoeli-Tlalim 2010, 2012). However, the effects on classification are somewhat more difficult to pin down and need further exploration.

\section{The Crystal Mirror (Shel Gyi Me Long)}

The Crystal Mirror was written by Gawai Dorje (Dga' ba'i rdo rje), a renowned doctor of Tibetan medicine of Chamdo, and published in Beijing in 1995. The text is in Tibetan but also contains Chinese names for most materia medica. Similar to the Crystal Garland of Medicine, the Crystal Mirror is largely concerned with descriptions of materia medica and contains nearly 900 color photos of most specimens discussed in the text.

In the Crystal Mirror, there are some remarkable changes in categories and overall classification from earlier treatments. Gawai Dorje divides materia medica into ten categories, which fall under three main divisions or "kinds" (rigs): Treasures (i.e., minerals, stones, salts); (exudents \&) Plants; and Animals (Table 4). This new hierarchical ordering in Tibetan medical texts seems driven by a concerted effort to organize materia medica into orders familiar to the modern subject: minerals, plants, and animals. While these divisions could have existed since the time of writing of the Four Tantras (Tibetans may have acknowledged some important differences between a rock, a tree, and a person, for example; common, although not universal, recognitions in many ethnobiological systems), they do not exist as overtly marked categories in the previous texts. In addition, the elaborated section on "animals" in the Crystal Mirror seems especially in keeping with contemporary scientific interpretations of the divisions between mammals, birds, reptiles, and insects (although the latter two get classed together in the text); these are divisions that do not exist in the Four Tantras or the Crystal Garland. These changes likely reflect the influence of modern science on traditional Tibetan conceptualizations of natural kinds-an influence that has increased significantly within the past several decades. 
Table 4. Categories of materia medica in the Crystal Mirror.

\begin{tabular}{|c|c|c|c|c|c|}
\hline $\begin{array}{l}\text { English } \\
\text { gloss }\end{array}$ & $\begin{array}{l}\text { Tibetan } \\
\text { name }\end{array}$ & $\begin{array}{l}\text { Subtypes } \\
\text { English gloss }\end{array}$ & $\begin{array}{l}\text { Subtypes Tibetan } \\
\text { name }\end{array}$ & $\begin{array}{l}\text { Sub-subtypes } \\
\text { (English \& } \\
\text { Tibetan) }\end{array}$ & Comments \\
\hline Treasures & $\begin{array}{l}\text { Gter } \\
\text { dngos kyi } \\
\text { rigs }\end{array}$ & $\begin{array}{l}\text { Precious } \\
\text { Medicine } \\
\text { Earth \& Stone } \\
\text { Medicine } \\
\text { Salt Medicine }\end{array}$ & $\begin{array}{l}\text { Rin po che'i sman } \\
\text { Sa rdo'i sman } \\
\text { Tshwa sna'i sman }\end{array}$ & & \\
\hline $\begin{array}{l}\text { Exudents } \\
\text { \& Woody } \\
\text { Plants } \\
\text { [Plants] }\end{array}$ & $\begin{array}{l}\text { Rtsi shing } \\
\text { gi rigs }\end{array}$ & $\begin{array}{l}\text { Exudent } \\
\text { Medicine } \\
\text { Woody Medicine } \\
\text { Herbaceous } \\
\text { Medicine } \\
\text { Grain Medicine }\end{array}$ & $\begin{array}{l}\text { Rsti } \\
\text { Shing } \\
\text { Sngo Idum } \\
\text { 'Bru'i }\end{array}$ & $\begin{array}{l}\text { [For category } \\
\text { of Shing]: fruit } \\
\text { ('bras bu) } \\
\text { flowers (me tog) } \\
\text { leaves (lo ma) } \\
\text { trunk/stems } \\
\text { (sdong po) } \\
\text { small branches } \\
\text { (yal phran) } \\
\text { bark (pags pa) } \\
\text { gum/sticky } \\
\text { matter/ exudent } \\
\text { (tshi ba thang } \\
\text { chu) }\end{array}$ & $\begin{array}{l}\text { This category can } \\
\text { best be understood as } \\
\text { close to the neologism } \\
\text { "plants," even though } \\
\text { the literal translation } \\
\text { does not appear to } \\
\text { include herbaceous } \\
\text { plants; the category } \\
\text { also includes non-plant } \\
\text { matter }\end{array}$ \\
\hline Animals & $\begin{array}{l}\text { Srog } \\
\text { chags kyi } \\
\text { rigs }\end{array}$ & $\begin{array}{l}\text { Mammals } \\
\text { Birds } \\
\text { Non-aquatic \& } \\
\text { aquatic } \\
\text { worms and } \\
\text { insects }\end{array}$ & $\begin{array}{l}\text { 'O thung sde } \\
\text { tshan } \\
\text { Bya rigs sde tshan } \\
\text { Skam chu gnyis } \\
\text { gnas dang 'bu srin } \\
\text { gyi sde tshan }\end{array}$ & & $\begin{array}{l}\text { The category of non- } \\
\text { aquatic \& aquatic } \\
\text { worms and insects } \\
\text { includes reptiles, fish, } \\
\text { and crustaceans. }\end{array}$ \\
\hline
\end{tabular}

The hierarchical restructuring introduced by Gawai Dorje has the added effect of imposing an overall ordering schema focused on material substance that is nonexistent in earlier texts. Since "kind" (rigs) ${ }^{1}$ becomes an organizing principle, categories of materia medica in the Crystal Mirror are all based on constitutional similarities of material substance based on a tripartite division of the natural world. These categories are not defined by considerations of preparation, habitat, root quality (as seems plausible for some categories in the Four Tantras) or, more generally, nature/essence (ngo bo) based on the five elements/energies. While the ten categories of materia medica in the
Four Tantras may be defined by slightly different criteria for each category (preparation, habitat, root quality), as those aspects relate to the nature/essence of a substance, the Crystal Mirror superimposes the over-riding criterion of type of material substance on all constituents, regardless of preparation, root quality, habitat, and efficacy. This superimposition creates categories that are calibrated and "equalized" to be based on the overriding principle of material substance; such a principle does not appear to exist in the Four Tantras. Even if one could argue that nature/essence is the primary principle according to which categories are recognized in the Four Tantras, such a principle 
is not based on substance but rather on the interactive energies of the five elements.

Both the Crystal Garland of Medicine and the Crystal Mirror are organized more according to physical characteristics than according to efficacy, as is the case in the Four Tantras and another central seventeenth century text, the Blue Beryl (not discussed in this paper). The Crystal Garland of Medicine marks a key historic moment of transition in the categorization of materia medica in the Tibetan medical written tradition, where there is refocusing on something akin to morphology as being the organizing principle of classification. Such a focus on morphology becomes even more important in the twentieth century text; in fact, the Crystal Mirror does not highlight efficacy as a topic in its own right, which is a significant development of the medical and pharmacological tradition.

\section{Categorization of Plants in Two Texts}

There are four main points of difference in plant categories (i.e., not all categories of materia medica) in the oldest and newest texts (the Four Tantras and the Crystal Mirror). These differences point toward likely influence from modern science, particularly a focus on morphology. First, whereas the Four Tantras does not categorize "plants" into a higher order, the Crystal Mirror does with the category rtsi shing gi rigs. For example, there are four plant-like categories in the Four Tantras, but the term rtsi shing is not in any of the categories, nor is it overtly marked as its own category, as is the case in the Crystal Mirror. The term rtsi shing appears to be a neologism that can be glossed as the general term "plant," or flora. It appears this is close to the meaning of the term as used in the Crystal Mirror, given that three of the four categories within this order include plant-only material exclusively. And yet, clearly, the category of rtsi (without shing) is one that includes non-plant materials and is based upon the characteristic of exuding a sticky substance (musk is such a substance, as is saffron); thus, the order rtsi shing cannot be translated strictly as "plants" in the context of medical texts. Indeed, in a local context, rtsi shing does not appear to mean the general term "plant" to most people that I worked with in Rgyalthang. Dr. Ma Liming, one of the doctors with whom I have worked extensively over the years in Rgyalthang, has had strong reservations about using rtsi shing as an accurate translation of the modern Chinese term "plant" (zhiwu). In fact, he explicitly stated that rtsi shing is an incorrect translation of zhiwu. Thus, the Crystal Mirror appears to be referring to rtsi shing as generalized "plant," although the use of this term in both written and spoken Tibetan in the medical context is complicated by other connotations of the term. (This is not the case for Chinese zhiwu and while in the field I found that zhiwu, a modern term derived from Japanese, was used most effectively both by myself and the doctors to refer to generalized plant or flora.) The lack of a generalized term for "plant" in the Four Tantras and in the Crystal Garland is not surprising and is, in fact, quite common in traditional systems throughout the world. The use of rtsi shing in the contemporary text the Crystal Mirror, then, likely reflects the influence of modernity and modern science, perhaps via Chinese language and, before that, Japanese language.

Second, the two texts differ in criteria for categorization. The Crystal Mirror uses physical characteristics, particularly morphology, as the primary determining characteristic for plant classification, whereas the Four Tantras classifies according to nature/essence as related to efficacy. Plants with especially "woody" stems (such as Rhododendron sp., Berberis sp., Juniperus sp., Rosa sp., Myricaria sp.) are categorized as Woody Medicine (shing sman) in the Crystal Mirror, rather than Herbal/Salad Medicine (sngo sman) as they are in the Four Tantras. Shug pa tsher can (Juniperus sp.; Figure 1) is a good example of this change. In the Four Tantras, this plant is 
classified under the category Herbal Medicine (sngo yi sman); in the Crystal Mirror, the same plant is classified under Woody Medicine (shing sman). Let us assume that shug pa tsher can refers to more or less the same plant in the two texts (exact species identification of shug pa tsher can in the Four Tantras may be impossible, but it is reasonable to assume that identification at the level of genus, Juniperus, is accurate). It seems to be classified as an herb (sngo) in the Four Tantras according to its nature/ essence (and according to its efficacy), whereas it is classified in the Crystal Mirror according to having the morphological characteristic of being "woody" (shing). Such a reclassification is existent in the Crystal Garland and may have been initiated by author Tenzin Phuntsok himself. The significance of this is that contemporary doctors utilize the classifications of later texts; they consider shug pa tsher can a "woody" medicine, not an "herbal" one. So, it appears that the importance of morphology as a determining characteristic in classification has had some effect on the classificatory schemata used by contemporary doctors, at least those with whom I have worked in Rgyalthang.

A third difference is that the category of Medicine from the Plains (thang sman) ${ }^{2}$ is dropped completely in the Crystal Mirror. The plants put in this category in earlier texts become classified in the Crystal Mirror according to morphology: those with woody stems get classified under Woody Medicine (shing sman) while those with herbaceous stems get classed under Herbal Medicine (sngo Idum sman). For example, sea buckthorn (star bu; Hippophae sp.; Figure 2) is classified in earlier texts as Medicine from the Plains, whereas it is classified in the Crystal Mirror as Woody Medicine. Inula racemosa (ma nu) (Figure 3) is also classi-

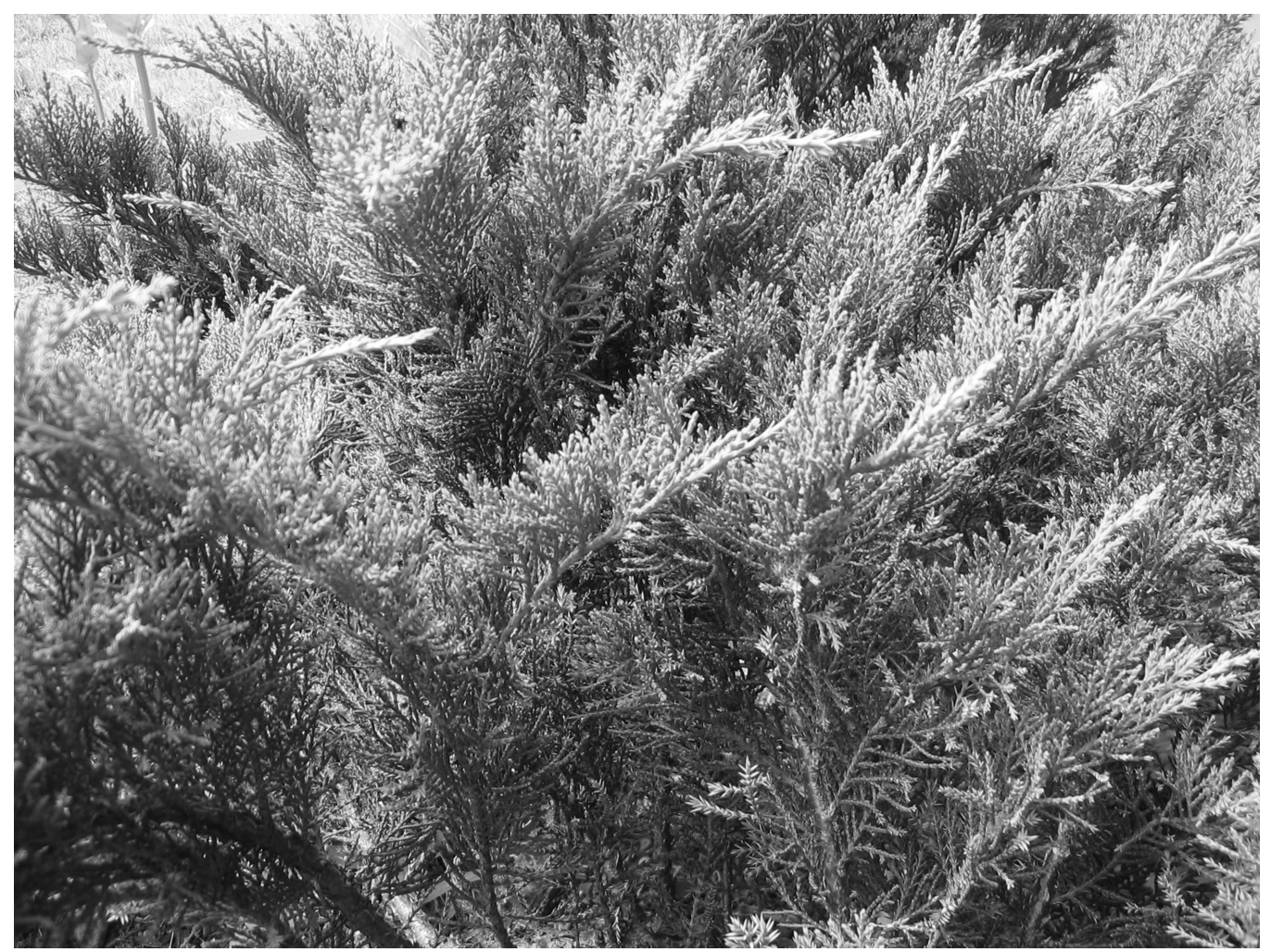

Figure 1. Shug pa tsher can (Juniperus sp.). Photo by Denise M. Glover 
fied as Medicine from the Plains in earlier texts but then classified as Herbal Medicine in the Crystal Mirror. Contemporary Rgyalthang doctors with whom I worked used the classificatory schema of the Crystal Mirror for both Hippophae sp. and Inula racemosa, at least in part (they also will classify these plants based more on efficacy when given particular tasks, such as pile sorts). Why is this category of thang sman no longer present in the Crystal Mirror? If we take Dash's (1995) and Rechung's (2001) interpretations of thang sman as "Decoctions," the omission of this category possibly signals that an earlier distinction in preparation becomes less important as a classificatory element. If we accept Dawa's (1999) interpretation of thang sman as being those plants with "strong roots," we could surmise that the quality of roots has become less important in classifying schemata. If Pasang Yonten Arya (1998), Yonten Gyatso (personal communication, 2005), and the doctors with whom I worked are correct that thang sman means "medicines from the plains," then perhaps where plants grow has less importance in current classifications. Whichever way we interpret the meaning of this category, the eliding of thang sman indicates that morphology becomes the overriding concept for classification in the Crystal Mirror. It is possible that the eliding of the category thang sman in recent texts published in the PRC could be due to a desire for standardization; since practitioners interpret this category in various ways (related to where plants grow, the quality of the roots, the type of preparation used), the elimination of this category could be related to reducing interpretive variation among practitioners and promoting a standardization that favors the primacy of morphology, since plants are reorganized according to this criteria. This is a shift from a more gnostic system of knowing, where interpretation is key, to an epistemic one where the "known" is standardized and not open to interpretation (Bates 1995).

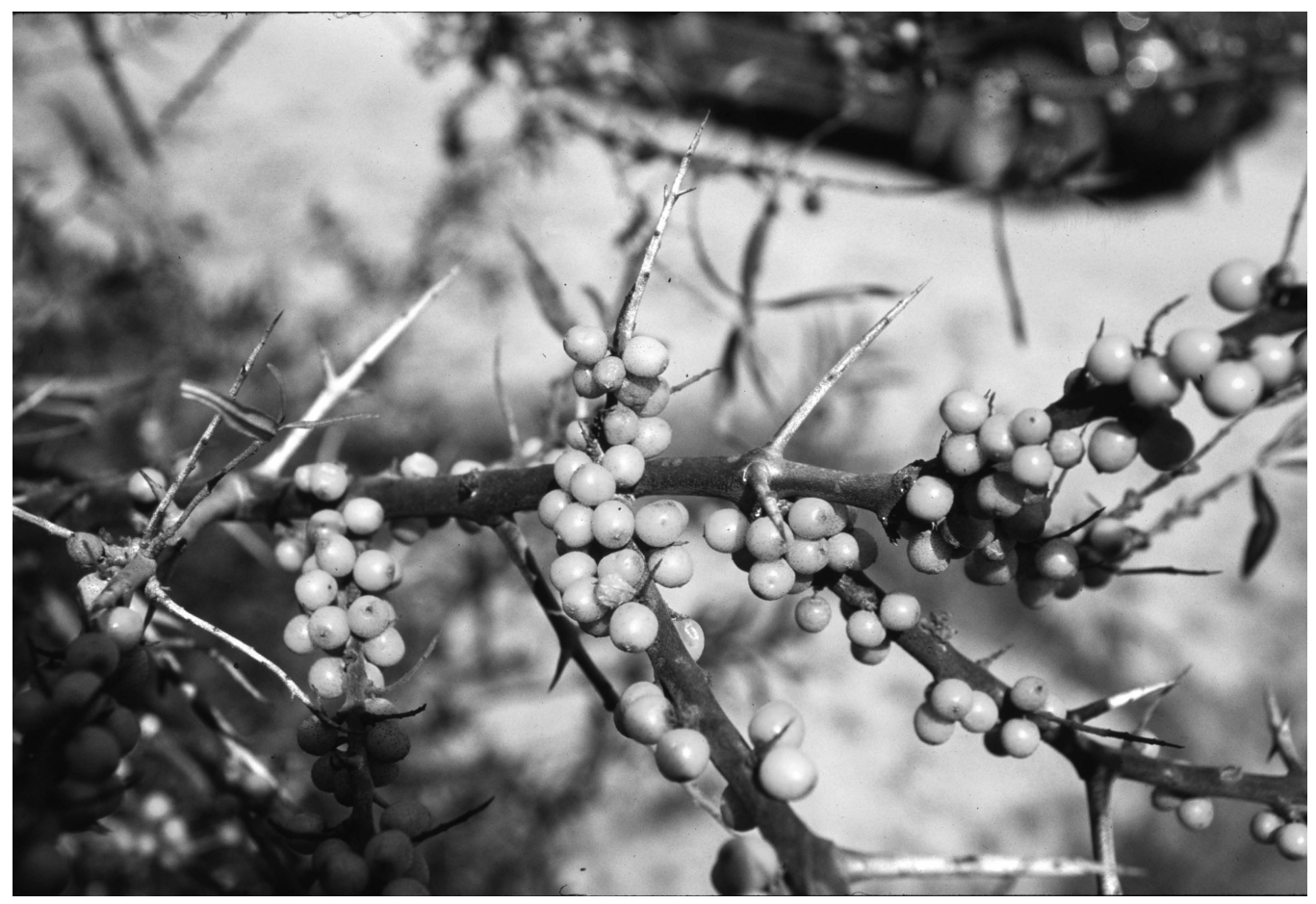

Figure 2. Star bu (Hippophae sp.). Photo by Daniel Winkler 


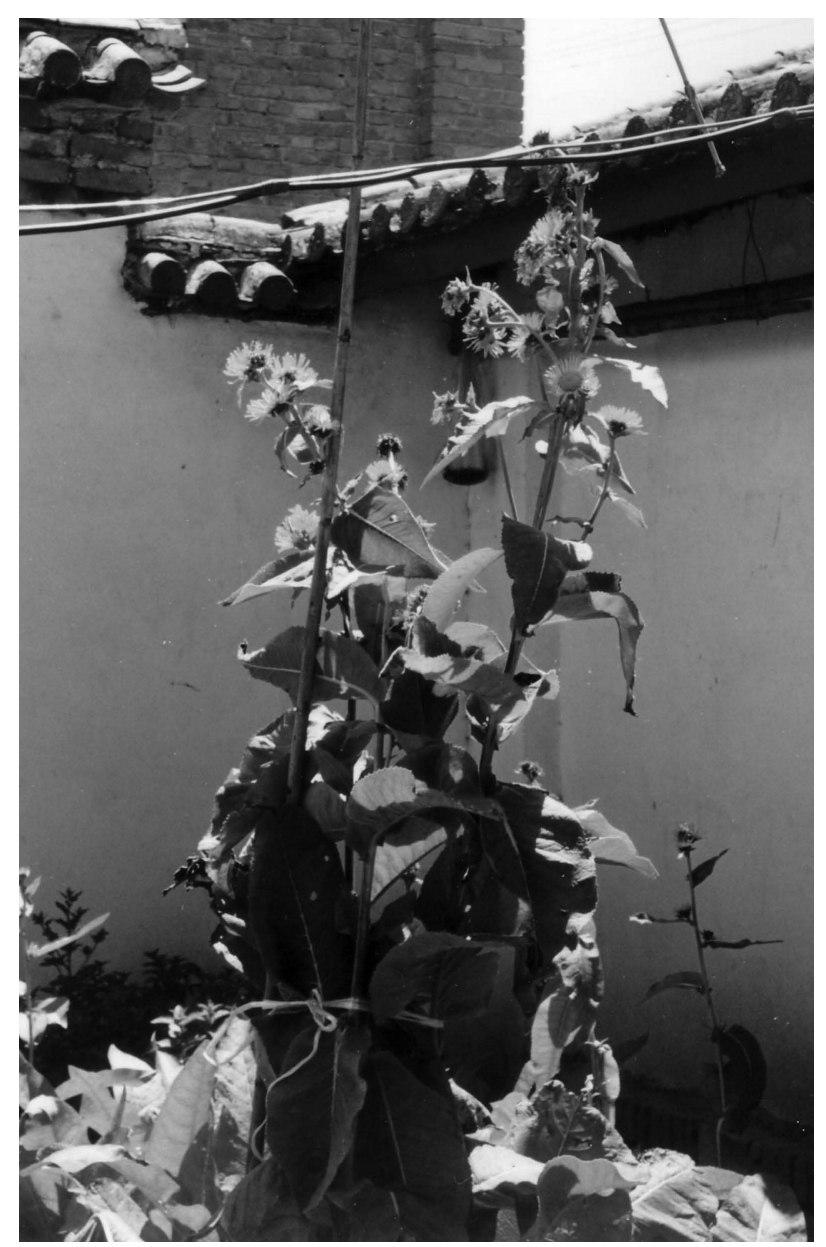

Figure 3. Ma nu (Inula racemosa). Photo by Denise M. Glover

A final difference between the Four Tantras and the Crystal Mirror is that the category of grain ('bru) is transferred from a type of foodstuff (zas) in the Four Tantras (Chapter 15) to one of medicine (sman) in the Crystal Mirror, under the category "Exudent [Mostly Plant] Medicine [rtsi shing rigs] $]^{3}$." The doctors with whom I worked readily admit that foodstuff has important medicinal properties and will prescribe eating or avoiding certain food as an important regimen of treatment, although foodstuff is not an ingredient in compounded medicines. I never heard doctors refer to such foodstuffs as medicines (sman) during the course of my fieldwork, although in a letter from one of my consultants, he indicated that crops (lo thog) are a type of "plant medicine" (skye dngos sman). Thus, it could be that grains are logically a type of medicine, but semantically they are thought more of as a type of food (an argument made by linguist Anna Wierzbicka [1984]). In the Crystal Mirror, however, grains are reclassified as plants, since this is the logical category under which grains fit best (they are certainly not minerals or animals). Again, the overriding concern with adhering to categories of modern science stands out.

\section{Discussion}

The influence of Linnaean science is the most general feature of materia medica 
classifications in the Crystal Mirror, as well as other contemporary medical texts in both Chinese and Tibetan. This influence is most apparent in the overall hierarchical structure of materia medica classification in the Crystal Mirror, where life-form ("kingdom") categories recognized by modern, Linnaean science (plant, animal, mineral) are those with the highest levels of inclusion ${ }^{4}$. Classification of plants in newer medical texts like the Crystal Mirror is based primarily on the principle of physical characteristics or morphology rather than that of nature/ essence, as in the Four Tantras. While physical characteristics may be a factor in a plant's nature/essence, it is not explained as such in the early medical texts; at least the particular nature/essence of a plant is not dependent upon physical characteristics, or morphology, alone. Nature/essence also depends on taste (ro), aftertaste (zhu rjes), and potency (nus pa), which are themselves dependent on the composition of the five elements. It is not so much that the Crystal Mirror ignores the important characteristics of taste, aftertaste, and potency, but rather that they are no longer organizing principles of classification, as they are in early texts. One could thus summarize that modern texts are organized more like texts of science than those of medicine, as the earlier texts are. While contemporary texts maintain important information about the medicinal uses and properties of plants, this information is no longer the central organizing principle of materia medica. This reorganization is in keeping with the dominance of western science in education and medical training in the modern nation-state of the PRC; therefore, part of the narrative we can construct here is one that highlights how Tibetan medicine has been influenced by the general spread of pre-twenty-first century modern science, particularly with Linnaean classification.

It should not come as a complete surprise that a text of Tibetan medicine written in 1995 was influenced by western science. But the contours of this encounter are more readily available for view through an examination of the classification system at work and the possible historical and cultural linkages leading up to the twentieth century are not cut and dried. As the analysis of the eighteenth century text the Crystal Garland demonstrates, some of these concepts (e.g., those about the centrality of physical characteristics) were present in the Tibetan medical worldview during the time of Linnaeus; whether there was direct cultural contact between Linnaean and Tibetan naturalists at this time is difficult to ascertain, but seems highly unlikely. As stated above, we do know that there were strong influences from Hippocratic-Galenic and Persian medical systems into Tibetan medicine by the thirteenth century, if not earlier. The musk, silk, salt, and tea trades all involved Tibetan-speaking populations interacting with peoples to the east and/or west, which resulted in exchange of ideas as well as material goods. There were other important cultural and political contacts between various European representatives and Tibetan politicians. For example, there were Portuguese missionaries in Lhasa (the capital of pre-1949 Tibet) in 1624; the Italian Jesuit scholar Ippolito Desideri was in Lhasa from 1716-1721. Perhaps the exchanges with these two European thinkers, and others, may have sparked new ways of thinking about the order of the natural world, if not direct influence on natural-kind classification. By the late twentieth century, it seems clear that the Linnaean worldview of a tripartite division of the natural world had become an organizing principle of key Tibetan medical texts, even though some of the classifications of western science, as exemplified in the Crystal Mirror, have not quite caught on (use of neologism rtsi shing as "plant"; category of grains ['bru] as medicine), at least among the doctors with whom I have studied. With the dominance of Linnaean classification waning in western science in the early twenty-first century, it will be interesting to see if/how/when new texts in 
Tibetan medicine reflect other systems of classification, or perhaps return to earlier schemata within the Tibetan tradition itself.

In terms of living, interactive acts of classification, Tibetan doctors with whom I have worked in Rgyalthang tend to follow the classifications of the Crystal Mirror in highlighting physical characteristics as an important classificatory principle. Yet such effects are not hegemonic, and they are largely dependent on context and function. In fact, it may be that the act of privileging physical characteristics as an important principle of classification-a new, possibly "modern" strategy in this medical tradition-is in part mitigated by the other classificatory schemata with which Tibetan doctors engage. In particular, during the course of research, I have found that classifying plants according to the disorder(s) they treat is an especially salient schema and has appeared as the most common way of classifying plants in sorting tasks that I have asked doctors to perform; classification according to disorder also permeates other classificatory schemata that doctors use (according to efficacy, taste, habitat, and cooling or heating properties). This type of classification (according to disorder) is specified in the Four Tantras (Book Two, Chapter 21) but not in contemporary texts, including the Crystal Mirror. Although modern texts do include information on which disorders plants treat, given along with information on taste, potency, physical description of the plant, its flowers, etc., none of them actually group plants by disorder(s) treated. This is revealing given the predominance of classifying plants by disorder among Tibetan doctors in Rgyalthang. It seems to indicate that although doctors adhere somewhat to the classificatory schemata of newer texts (shug pa tsher can is considered a type of Woody Medicine, in accordance with the Crystal Mirror, for example) they also utilize a system of classification that has not been modified for centuries: classification by disorder. This points to the complexity of plant and materia medica classifications among Tibetan doctors, as multiple classificatory schemata are used for multiple functions (identification, diagnosis, treatment, pharmacology, etc.). In addition, it shows that both contemporary and historical texts are influential in the cognitive worlds of these doctors as they continue to practice the art and science of Tibetan medicine in the PRC.

There are many lacunae that need filling in-and many unanswered questions-in terms of understanding the specific changes that have occurred in materia medica classification in the Tibetan medical tradition. From what we can tell thus far, the narrative of classification explored herein includes likely influence from outside the Tibetan cultural-linguistic world, including from Linnaean science, as well as possible innovation from within the Tibetan medical tradition itself. While we need more information to fill out the narrative, there is much to be gained by studying changes in classificatory schemata over time, rather than focusing on classificatory systems as static arrangements. Such a study is possible in the case of materia medica in the Tibetan tradition because of the "special-purpose" and supra-generic folk (Berlin 1992) nature of these classifications, which are more likely to be revealing of cultural, historical, and functional shifts. Thus, the diachronic approach is more possible with certain types of classificatory systems than others. An approach to classification as a form of narrative aids in reminding us that, just as culture is not a static state of existence or set of learned behaviors, but an evolving and adaptive system with dynamism and intra-variability, so may be some systems of natural-kind classification. This dynamism can help explain variations that may exist in a current, living system of classification, where multiple schemata are at work and in interaction with each other. Orienting this way, we will likely continue to find captivating narratives of socio-cultural, political, and historical change in a world of diachronic classificatory intrigue. 


\section{Notes}

'The level of these divisions would equate probably more directly with English "kingdom" but I have chosen to retain the more literal meaning of the Tibetan term rigs. Rigs is used in terms such as mi rigs (human kind, humanity; also used to translate Chinese 民族 minzu, "nationality" or "ethnic group," although literally "people kind") where the meaning is clearly not as general as "kingdom."

${ }^{2}$ Rgyalthang doctors do not appear to use the category thang sman very much. Once in the field when I asked my main consultant, Ma Liming, about this category he said that thang sman is actually a sub-category of sngo sman. Later, after my fieldwork was complete and I was closely examining the categories of texts, I wrote to Dr. Ma and asked about the meaning of thang sman. He wrote back and explained that the Tibetan thang means "plains" and that the Chinese equivalent is 平坝上药 pingba shang yao (literally, "medicine on the plains"). In my letter I mentioned that I have seen other works that explain this category as being decoctions, and suggested that perhaps the thang is actually from Chinese 汤 tang ("soup"); he responded that this is incorrect. There is a difference, he noted, between thang sman and sman thang, the latter term which means decoctions (Chinese 汤药 tang yao). Dr. Ma's interpretation is corroborated by Pasang Yonten Arya's work as well as by Yonten Gyatso (personal communication, 2005) but is in contrast with that provided by Dash (1995) and Rechung (2001) and possibly Dawa (1999).

${ }^{3}$ In the Crystal Garland, grains are categorized under the class of "Crop medicine from the fields" (zhing gi lo thog las byung ba'i sman) and this may have been the transitioning point were grains moved from being a type of foodstuff (crops) to being labeled a type of medicine (sman).

${ }^{4}$ Biologists in the twenty-first century now argue that there are at least five major kingdoms or, in some schemas, three major domains (above the level of kingdom) of organic life, with minerals being excluded from these classifications (since they are not biological). Yet I would argue that the Linnaean approach can still be considered "modern" in that it has held sway in the natural sciences until quite recently and may in fact continue to be the more influential schema to the modern subject (except those trained in biology).

\section{References Cited}

Akasoy, A., C. Burnett, and R. Yoeli-Tlalim. 2016. Islam and Tibet: Interactions along the Musk Routes. Routledge, New York.

Arya, P. Y. 1998. Dictionary of Tibetan Materia Medica. Motilal Banarsidass Publishers, Delhi.

Bates, D. 1995. Scholarly Ways of Knowing: An Introduction. In Knowledge and the Schol- arly Medical Traditions, edited by D. Bates, pp. 1-22. Cambridge University Press, Cambridge.

Berlin, B. 1973. Folk Systematics in Relation to Biological Classification and Nomenclature. Annual Review of Ecology and Systematics 4:259-271.

Berlin, B. 1992. Ethnobiological Classification: Principles of Categorization of Plants and Animals in Traditional Societies. Princeton University Press, Princeton.

Berlin, B., D. E. Breedlove, and P. H. Raven. 1973. General Principles of Classification and Nomenclature in Folk Biology. American Anthropologist 75:214-242.

Birkhead, T. 2008. The Wisdom of Birds: An Illustrated History of Ornithology. Bloomsbury, New York.

Brown, C. H. 1984. Language and Living Things: Uniformities in Folk Classification and Naming. Rutgers University Press, New Brunswick, NJ.

Brown, C. H. 1985. Mode of Subsistence and Folk Biological Taxonomy. Current Anthropology 26:43-64.

Brown, C. H., C. R. Clement, P. Epps, E. Luedeling, and S. Wichmann. 2013. The Paleobiolinguistics of Domesticated Chili Pepper (Capsicum spp.). Ethnobiology Letters 4:1-11.

Bstan 'dzin Phun tshogs. 1980. Shel Gong 'Phreng (Full title: Bdud nad gzhom pa'i gnyen po rtsi sman gyi nus pa rkyang bsad gsal ston dri med shel gong zhes bya ba bzhugs so). Bod sman Sman khang, Zha ho zhan (夏河县).

Bulmer, R. 1967. Why is the Cassowary Not a Bird? A Problem of Zoological Taxonomy among the Karam of the New Guinea Highlands. Man (N.S.) 2:5-25.

Dash, V. B. 1994. Encyclopaedia of Tibetan Medicine, vol. $1 \& 2$. Sri Satguru Publications, Delhi.

Dash, V. B. 1995. Encyclopaedia of Tibetan Medicine, vol. 3 \& 4. Sri Satguru Publications, Delhi.

Dash, V. B. 1997. Tibetan Medicine: Theory and Practice. Sri Satguru Publications, Delhi. 
Dash, V. B. 1998. Encyclopaedia of Tibetan Medicine, vol. 5. Sri Satguru Publications, Delhi.

Dash, V. B. 1999. Encyclopaedia of Tibetan Medicine, vol. 6. Sri Satguru Publications, Delhi.

Dawa, D. 1999. A Clear Mirror of Tibetan Medicinal Plants, vol. 1. Tibet Domani, Rome.

Dga' ba'i Rdo rje. 1995. Shel gyi Me long (Full title: 'Khrungs dpe dri med shel gyi me long). Mi rigs dpe skrun khang, Beijing.

Ellen, R. F. 1993. The Cultural Relations of Classification: An Analysis of Nuaulu Animal Categories from Central Seram. Cambridge University Press, New York.

Ellen, R. F., and D. Reason, eds. 1979. Classifications in Their Social Context. Academic Press, San Francisco.

Finckh, E. 1978. Foundations of Tibetan Medicine: According to the Book rGyud bźi, Vol. 1. Watkins, London.

Garrett, F. 2007. Critical Methods in Tibetan Medical Histories. Journal of Asian Studies 66:363-387.

Glover, D. M. 2005. Up from the Roots: Contextualizing Medicinal Plant Classifications of Tibetan Doctors in Rgyalthang, PRC. Unpublished Doctoral Dissertation, University of Washington, Seattle.

Glover, D. M. 2010. Classes in the Classics: Historical Changes in Plant Classification in Two Tibetan Medical Texts. In Studies of Medical Pluralism in Tibetan History and Society, edited by S. Craig, M. Cuomu, F. Garrett, and M. Schrempf, pp. 255-277 International Institute for Tibetan and Buddhist Studies, Contributions to Research on Central Asia Series, Bonn.

Glover, D. M. 2011. Absorbing Text: Internalizing Knowledge of Medicinals through Sensory Experience of Texts. Paper presented at the Plenary Session of the $34^{\text {th }}$ Annual Conference of the Society of Ethnobiology. Columbus, Ohio, May 4-7.

Hunn, E. 1975. A Measure of the Degree of Correspondence of Folk to Scientific Biological Classification. American Ethnologist 2:309-327.
Hunn, E. 1976. Toward a Perceptual Model of Folk Biological Classification. American Ethnologist 3:508-524.

Hunn, E. 1982. The Utilitarian Factor in Folk Biological Classification. American Anthropologist 84:830-847.

Millard, C. 2002. Learning Processes in a Tibetan Medical College. Unpublished Doctoral Dissertation, University of Edinburgh.

Rechung, R. J. K. 2001. Tibetan Medicine: Illustrated in Original Texts. Sri Satguru Publications, Delhi.

Rgyud bzhi. 1978. (Full title: Bdud rtsi snying po yan lag brgyad pa gsang ba man ngag gi rgyud) A Reproduction of a Set of Prints from the 1888 Lha-sa Lcags-po-ri Blocks. Smanrtsis Shesrig Spendzod series, Volume 87. T.S. Tashigangpa, Leh, Ladakh.

Sabernig, K. 2016. The History of Anatomical Paintings. Paper presented at Lhasa Mentsikhang, Lhasa, TAR, PRC. August 19.

Sde srid Sangs rgyas Rgya mtsho. 1973. Bai dur sgnon po (Full title: Gso ba rig pa'i bstan bcos sman bla'i dgongs rgyan rgyud bzhi'i gsal byed bai dur sngon po'i ma lli ka). Reproduced from a Print of the 1888-1892 Blocks Preserved in the Lha-sa Lcags-po-ri Rig-byed 'Gro-phan-gling. Smanrtsis Shesrig Spendzod, vol. 51. T. S. Tashigangpa, Leh, Ladakh.

Wang, L. 1994. The Medical History of Tibet. Foreign Language Press, Shanghai.

Wierzbicka, A. 1984. Apples are Not a "Kind of Fruit": The Semantics of Human Categorization. American Ethnologist 11:313-328.

Yoeli-Tlalim, R. 2010. On Urine Analysis and Tibetan Medicine's Connections with the West. In Studies of Medical Pluralism in Tibetan History and Society, edited by S. Craig, M. Cuomo, F. Garrett, and M. Schrempf, pp. 195-211 PIATS 2006 Proceedings of the $11^{\text {th }}$ Seminar of the International Association for Tibetan Studies. International Institute for Tibetan and Buddhist Studies.

Yoeli-Tlalim, R. 2012. Re-visiting 'Galen in Tibet.' Medical History 56:355-365. 